\title{
Exclusão e marginalidade no reino de Castela: O judeu nas Siete Partidas de Afonso X
}

\begin{abstract}
Resumo: A presença judaica no mundo medieval ibérico era delineada pelas normas gerais que a Cristandade Ocidental definira para os seguidores da Lei de Moisés complementada por uma legislação específica de origem local. Tentaremos analisar as Siete Partidas ${ }^{1}$ a partir da legislação geral da Cristandade e também no âmbito do mundo hispânico medieval. Esta escolha foi formulada a partir da concepção de que no seio desta codificação ocorre a confluência de concepções teológicojurídicas sobre os judeus, originadas no final do mundo antigo, no período do Baixo Império e nos primórdios da Idade Média, lado a lado com as novas concepções sobre os judeus, originadas no seio da Cristandade Ocidental no período da expansão européia ocorrida a partir do ano Mil.
\end{abstract}

Palavras-chave: Judeus; Siete Partidas; Afonso X; Castela; Exclusão.

\section{Introdução}

Agostinho e Gregório Magno: a função dos judeus na Cristandade

O que significa a expressão, legislação geral da Cristandade? Trata-se de um termo genérico num mundo politicamente pulverizado sob um modelo de governo descentralizado que apenas começava a voltar-se na direção de

\footnotetext{
- Professor Adjunto de Historia Medieval - Departamento de História Universidade Federal do Espírito Santo - UFES - 29.075-910 - Vitória ES - Brasil. E-mail: serfeldpr@hotmail.com

$\mathrm{O}$ artigo é parte de uma pesquisa patrocinada pelo CNPq.
} 
uma centralização monárquica, a passos lentos. $\mathrm{E}$ em contraponto com este tímido renascimento do Estado, vemos um Papado forte e poderoso que tinha como modelo e referência um expoente como o hierocrata Inocêncio III. De onde provinha a definição de uma tendência geral na jurisdição sobre os judeus?

O olhar teológico-jurídico da Cristandade Ocidental sobre os judeus até o século XIII estava moldado a partir de duas tendências dominantes, ambas derivadas da concepção de $\mathrm{S}$. Agostinho sobre a presença de judeus no mundo cristão. Agostinho definira a condição dos judeus a partir de seu papel na recepção da Revelação e na sua função de antecessores da Igreja.

Em toda a sua obra, porém, especificamente na sua opus magna, a Cidade de Deus, e também no seu Adversus Judaeos, o bispo de Hipona desenvolveu o conceito segundo o qual os judeus deveriam ser dispersos pela Cristandade, submetidos aos poderes laicos e eclesiásticos e inferiorizados juridicamente. Para ilustrar suas idéias sobre o tema, fez o uso alegórico de trechos dos Salmos, tal como o que se segue, para justificar sua posição: "Não os mates, para que não se esqueçam nem um dia de tua Lei; dispersa-os com o teu poder". ${ }^{2}$ (AGOSTINHO, 1995: L. XVIII, c. 46: 1832)

Dessa maneira, Agostinho constrói o conceito de povo testemunha, uma reflexão teológica pela qual tenta resolver o enigma da sobrevivência judaica e, ao mesmo tempo, sua situação degradante. No mesmo trecho, conceitua que se trata de vontade divina: "Mostrou Deus assim à sua Igreja a Graça de sua misericórdia para com seus inimigos judeus". São degradados, inferiorizados e dispersos por todo o mundo: "Por isso não os matou, isto é, não lhes tirou o que tinham de judeus, apesar de vencidos e oprimidos pelos romanos". E qual a razão de Deus de mantê-los assim? O bispo de Hipona analisa que seria para que, dispersos, possam fornecer o testemunho das Escrituras e de Cristo:

Dispersa-os porque, se eles, com este testemunho das Escrituras, estivessem apenas na sua terra,e não estivessem em toda a parte 
não poderia a Igreja, que em toda a parte está, tê-los como testemunhas, entre todos os povos, das profecias que se anunciaram acerca de Cristo (AGOSTINHO, 1995: L. XVIII, c. 46, p. 1833).

São ao mesmo tempo testemunhas do demônio e da verdade cristã, nas palavras de Agostinho, "testes iniquitatis et veritates nostrae"; na sua visão, subsistem para a salvação da nação, mas não para a sua própria (AGOSTINHO, 1865: PL, t. 36, col. 705, 58, 1 e 22). São uma espécie de "testemunha das Escrituras", e Agostinho considera-os como se fossem um "bibliotecário-escravo" (AGOSTINHO, 1865: PL, t. 36, col. 666, c. 56, v. 9) ${ }^{3}$. A sua desgraça e dispersão são parte do testemunho. Alguns analistas denominam esta condição como "povo testemunha", e tal postura explica a sobrevivência judaica e sua tolerância no seio da Cristandade, sob um status de inferioridade.

Agostinho insere-se numa linha teológica que aceita a presença judaica no seio da Cristandade sob limitações e inferioridade, ainda que adote também uma postura não radical de evangelização dos judeus. É claramente um discípulo de Paulo de Tarso, pela sua moderação relativa no que tange aos judeus. Vale ressalvar que, na sua concepção escatológica, os judeus são inseridos na finalidade da História: a segunda vinda de Jesus depende da conversão deles à Verdade cristã e de sua inserção no seio da Igreja. Culpados de deicídio no passado, cegos no presente e entrave à promissora e futura Redenção. $O$ papel judaico no processo histórico não os marginaliza de maneira absoluta: degrada sua condição social e política no presente e os coloca como elemento chave para a consecução do projeto divino, para a finalidade da História. Agostinho não pode ignorar esta problemática na construção de sua Filosofia da História (FELDMAN, 2008) ${ }^{4}$.

Não podemos perder de vista que a construção agostiniana se formatou sob a égide do legalismo baixo-imperial. Os judeus eram considerados uma religião aceita e protegida sob as leis do Império (FELDMAN, 2001). A sua condição de religio licita é 
anterior ao surgimento da Cristandade, ultrapassará o período de soberania imperial no Ocidente e penetrará na legislação bárbara. Assim, há uma forte influência agostiniana e uma presença de média e longa duração da legislação romana imperial, reformatada no Codex Theodosianus e nas leis dos reinos germânicos que as reciclaram de maneira abreviada e simplificada, como veremos adiante. O nosso intuito neste breve estudo é verificar e destacar essas médias e longas durações na legislação castelhana.

Outro pilar dessa relação e dessa continuidade jurídica é o Papa Gregório, o Magno. Gregório consolidou as relações do papado com as novas monarquias bárbaras, inclusive com a Hispânia visigótica. Em seu breve e profícuo pontificado, estabeleceu relações com as nascentes monarquias, definiu posturas e atitudes que tiveram médias e por vezes até longas durações. Uma destas é relativa aos judeus. Gregório não permitiu abusos e transgressões que alterassem o status jurídico judaico. Ele era adepto de manter todos os direitos adquiridos e definidos na lex imperial, mas não agregar nada mais (MARCUS, 1938: 111-113). Entre ele e Agostinho há uma relação clara: ambos optam pela manutenção dos judeus sob a Cristandade num status jurídico de inferioridade na sociedade ampla, mas dotados de autonomia jurídica nos assuntos internos da comunidade judaica. Agostinho não tinha como legislar, já Gregório tinha auctoritas, visto sua condição de papa.

A clássica expressão Sicut judaeis non, de autoria dele, antecederá a maior parte das bulas papais relativas aos judeus pelo menos até Inocêncio III, no início do século XIII, dando sanção e validade às mesmas, visto o seu inabalável prestígio. Foi crítico exacerbado e ostensivamente ativo na questão da posse de escravos pelos mercadores judeus. Temia a conversão dos mesmos pelos seus senhores (SCHLESINGER; PORTO, 1973: 40-41). Tampouco aceitava as conversões forçadas de judeus e sugeria a evangelização através do convencimento e da pregação. Já na questão da destruição e confisco de sinagogas já existentes, foi ferrenho defensor da sua restauração no caso de queima e de sua devolução no caso de confisco e 
EXCLUSÃO E MARGINALIDADE NO REINO DE CASTELA:...

transformação em igrejas. Em contraponto, não admitia construção de novas sinagogas. Na opinião de Ben Sasson:

El enfoque de Gregório provenia de su própria perspectiva teológica, y reflejaba su carácter misionero y su técnica administrativa. Mas tarde, habría de servir de guia para toda actitud moderada observada hacia los judíos durante la Edad Media (1988: 483).

A partir de Agostinho, há uma legislação e uma postura fundamentada em suas idéias e também na legislação e opiniões de Gregório, que se consolida. Até pelo menos meados do século XIII, na Cristandade Ocidental, adotou-se uma regulamentação baseada na concepção agostiniana de História e na tolerância relativa dos judeus, sob condições de inferioridade e controle de sua influência em todos os âmbitos da sociedade, evitando a contaminação da sociedade cristã. $O$ que pretendemos demonstrar neste breve artigo é que há uma continuidade e uma média e por vezes até longa duração na persistência de uma legislação que se altera e muda em alguns detalhes, mas persiste na delimitação e no controle dos judeus sob uma ótica fundamentada nos princípios agostinianos. O desaparecimento da lei romana no Ocidente e seu ressurgimento nos séculos XII e XIII não alteram este panorama porque, no que tange aos judeus, a legislação canônica preservou resquícios do status jurídico judaico sob a formatação agostiniana. E as monarquias bárbaras inseriram excertos da lex romana, que por sua vez persistiram nos corpora jurídicos dos reinos. O nosso recorte tentará partir do geral para o específico e enfocará a Hispânia ou Península Ibérica, a partir do Baixo Império e fechando o foco em Castela Medieval.

\section{Eixos principais e posturas práticas. Média e longa duração}

Os eixos principais da tolerância à presença judaica podem ser definidos como sendo: a) o rígido impedimento do 
proselitismo judaico sobre fiéis cristãos e mesmo o controle da conversão de pagãos ou infiéis em geral ao Judaísmo; b) a proibição da conversão forçada de judeus ao Cristianismo, mesmo se fosse estimulada a tentativa de evangelização e proselitismo dos judeus à fé cristã; c) a definição de tempos e espaços proscritos aos judeus, ou seja, nos quais os judeus não transitem e nem dialoguem com cristãos e destes tampouco se aproximem; d) a proteção física dos judeus tendo como troca o usufruto dos mesmos pelos governantes para suprir funções sociais tidas como necessárias, seja no campo das finanças e comércio, seja na medicina; e) de maneira contraditória com o item anterior, enfatiza-se a não concessão de cargos e funções de poder que propiciem aos judeus serem superiores e influentes em relação aos súditos da Santa Igreja. Todos estes têm presença e validade, tanto no final do mundo antigo quanto na Alta e Baixa Idade Média.

Há dois princípios norteadores centrais que delineiam as relações cristãs judaicas desde o final do Mundo Antigo e durante boa parte da Idade Média. O primeiro princípio é a tolerância, no sentido agostiniano do termo. Os judeus cumprem função socioeconômica, mas o que legitima sua presença é a sua função na finalidade da História cristã (KRIEGEL, 2006: 41-42). Serão tolerados no presente, em função de seu papel no passado como receptores da Revelação que anunciava a vinda do Cristo, e de seu papel no futuro, quando uma parte deles se converteria e propiciaria a segunda vinda do Cristo e o Juízo Final. Esta postura permitia que os reis e por vezes elementos da nobreza e do alto clero pudessem usufruir de seus importantes serviços e justificar assim sua tolerância. Assim, a sua função socioeconômica deriva de sua condição sócio-religiosa. Puderam cumprir com as funções intermediárias só e a partir de sua exclusão e controle como um grupo separado e demarcado através da sua função na História cristã.

O segundo princípio é o aviltamento. Baseado no trecho dos Salmos que justifica a postura agostiniana, reduz-se a minoria judaica a uma condição de inferioridade (KRIEGEL, 2006: 41-42). Diz o salmista: "Não os mates, para que o meu povo não 
se esqueça; espalha-os pelo teu poder, e abate-os, ó Senhor, nosso escudo" (BIBLIA, SALMOS: 59, 11) ${ }^{5}$. A percepção social da condição judaica serve de outdoor da fé, ou seja, mostra o que ocorre com os que são cegos e pertinazes na suas crenças e não aceitam a verdade que só a Igreja pode oferecer. Passa a ser um modelo de uma postura errônea e antissocial. Assim, denegrir e inferiorizar os judeus é peça chave para a compreensão da teologia cristã e da finalidade da História.

$\mathrm{Na}$ prática, esta concepção alterna posturas práticas ora radicais, como no reino visigótico de Toledo sob o catolicismo (589-711) onde ocorreram conversões forçadas e perseguições aos judeus ou aos convertidos de origem judaica, ora de uma tolerância bastante ampla que resultava, por exemplo, na proteção de monarcas aos judeus em função de seu papel na economia e na administração. Este foi o caso do Império Franco sob Carlos Magno e, especialmente, Luis, o Pio. A Igreja criticava e reagia, mas o Imperador protegia os judeus, considerando-os súditos diretos da Coroa. A Alta Idade Média é um período de relativa tolerância e manutenção dos judeus sob a proteção dos reis, de uma maneira geral. O caso visigótico é mais uma exceção do que uma tendência neste período.

Quando a Cristandade Ocidental se transforma e retoma o crescimento demográfico readquirindo a pujança econômica e militar, a partir dos séc. X e XI, o panorama altera-se e isso se torna perceptível através das mais diversas expressões desta mudança. O crescimento demográfico, o renascimento urbano e comercial, o avanço econômico, a expansão militar e o rompimento dos limites territoriais são algumas destas alterações. O olhar cristão sobre o judeu também se altera: a princípio, na Inglaterra e na França. De maneira parcial, no fragmentado Império, tanto na Germânia quanto na Itália. Nos reinos ibéricos, este fenômeno não ocorre em paralelo, tardando a ocorrer. Os massacres das Cruzadas e as expulsões da Inglaterra (séc. XIII) e França (séc. XIII e XIV) ecoam no mundo ibérico e geram efeitos apenas de maneira parcial. A região gravita entre a relativa tolerância agostiniana e o preconceito intenso que grassa na Europa Ocidental. 
Por quê? No nosso entendimento, os reinos ibéricos eram uma espécie de periferia da Cristandade Ocidental. A presença e o contato com o Islã geravam trocas comerciais e trocas de saberes e certo tipo de tolerância em tempos de paz. No âmbito das relações com a Europa cristã, os fluxos de pessoas, tanto através das peregrinações ao santuário de Santiago de Compostela, quanto por meio das Cruzadas ocidentais, a assim denominada Reconquista relaciona-se a momentos que geram um intercâmbio de vários níveis. Chegam os modelos religiosoartísticos, tanto o românico quanto o gótico, aparecem ordens monásticas tais como Cluny, no início da expansão da Reconquista, os dominicanos e os franciscanos no séc. XIII; e nesse mesmo contexto de mudanças, um novo olhar sobre os judeus difunde-se no movimento de ideias e pessoas que se direciona para a PI.

$\mathrm{Na}$ nossa percepção, a legislação judaica presente nas Siete Partidas reflete essa transição. Há permanências e continuidades de leis e posturas clericais ou governamentais que remontam ao final do Baixo Império e que estão repletas de uma moderada dose de tolerância aos judeus, porém, lado a lado com as novas tendências que fluem dos Pirineus vindas da Europa Ocidental e que estão repletas de hostilidade e de uma concepção do judeu como uma entidade maligna e até satânica. Além disso, o renascimento do Direito romano, sob a forma do Codex de Justiniano, demarca sua presença nas Siete Partidas e em outras leis editadas por Afonso X (BAER II, 1981: 93).

Vale ressalvar que as leis são por vezes contraditórias com a realidade e nem sempre espelham as tensões sociais. Seu caráter ordenador e conservador refletem muito mais permanências e continuidades, do que as novas tendências sociais. Tendo esse cuidado, o nosso intuito é tanto verificar as longas e médias durações na legislação de Afonso X, o Sábio, quanto a realidade que se renova e amplia, mesmo se esta é menos perceptível. 
EXCLUSÃO E MARGINALIDADE NO REINO DE CASTELA:...

\section{A legislação antijudaica entre a continuidade e as novas tendências}

O cerceamento da presença judaica e a disposição dos poderes laicos e eclesiásticos de conter a possibilidade de expansão do Judaísmo é uma constante, tanto na legislação baixo imperial e dos reinos germânicos, quanto nos cânones conciliares. A presença judaica no seio da Cristandade ocidental, como já dissemos, tivera momentos de extrema tensão, tal como sob os visigodos convertidos ao catolicismo (589-711) e de tolerância e proteção dos imperadores carolíngios. $\mathrm{O}$ renascimento urbano e comercial nos séculos X e XI, lenta e gradualmente, gera tensões sociais e conflitos de grupos que almejam ocupar o espaço dos judeus no comércio e nas cidades em processo de reestruturação ou criação. O antigo se agrega ao novo. A Igreja alimenta estas tendências com os velhos estereótipos da malignidade e da culpa judaicas. O terreno é fértil e propício à proliferação de mitos embasados em fatores sobrenaturais: deicídio, crime ritual, profanação das hóstias, envenenamento de poços ou remédios, magias e aliança com o Diabo.

Não se pode falar de uma concepção social uniforme: no alto clero e entre os poucos letrados há um olhar diferente daquele existente no seio da religiosidade popular. A circularidade das ideias gera uma interação e uma síntese filtrada através do olhar sobrenatural e do preconceito. $O$ que acaba prevalecendo e tendo continuidade são os mitos e a construção do judeu imaginário: deicida, usurário e satânico. A crise religiosa gerada pela ausência de uma reforma efetiva da Igreja nos séculos X e XI e a propagação de heresias dualistas no sul da Europa nos séculos XI a XIII origina uma reação radical da Igreja. O mito de uma conspiração do Diabo com seus aliados: hereges, judeus e outros grupos marginalizados são os alvos deste combate. Não centraremos nosso olhar nesta direção. Nosso foco se propõe a analisar o jurídico e o social e suas imbricações. 
Na sequência da difusão do mito conspiratório anticlerical, vêm as alterações teológico-jurídicas. Inocêncio III define uma legislação que, em princípio, se propõe a manter a tolerância aos judeus sob o modelo agostiniano, mas de uma maneira cada vez mais minimalista (MARCUS, 1938: 137-141). Suarez Fernandez denomina esta codificação sob o nome de Constitutio pro iudaeis, a qual define e equaciona um mínimo de direitos que os reis poderiam dispor aos judeus de seus reinos (1992: 15-16). O mesmo autor concorda conosco ao afirmar que a:

[...] Constitutio pro iudaeis (1199), estableció lo que podíamos llamar el cuadro mínimo de derechos que los reyes debían otorgar a los judios, siguiendo siempre la pauta del pensamiento agustiniano (SUAREZ FERNANDEZ, 1992: 15-16).

Carpenter considera que a justificativa para essa tolerância segue na linha tradicional que concebe os judeus como servos e humilhados sob a égide da Cristandade para pagar por sua participação na morte de Jesus (1986: 61).

Igualmente, seu papel na segunda vinda de Cristo gerava a expectativa de que uma parcela dos judeus ainda se converteria e se salvaria no Juízo Final.

A rigidez e o aumento da pressão das forças sociais sobre a minoria judaica vêm penetrando desde a Europa Ocidental na direção da Península Ibérica. É como um movimento de idéias e estereótipos que se movimenta e que transpõe os Pirineus, chegando a Navarra e Aragão, de onde transita para Castela, quase na sequência. Portugal é o último lugar onde os judeus conseguem viver de maneira razoável no século XIV e no XV quase todo. Tal como a influência artístico-religiosa do românico e depois do gótico na arquitetura eclesiástica, tal como os peregrinos afluíam ao Caminho de Santiago e deixavam influências espirituais - e neste movimento ocorriam trocas culturais entre a península e o resto da Europa -, há um fluxo de ideias e de gestos que impregnam o ambiente peninsular com a intolerância e a discriminação. Os reis tentam obstar esta corrente de preconceito e proteger os judeus que em números 
expressivos eram leais servidores da Coroa. Constrói-se assim uma luta contra o tempo: os judeus começam a ser ameaçados de perder a tranquilidade de viver nos reinos cristãos ibéricos.

Há um tipo incomum de coerência na postura dos reis, que ora protegem e ora legislam leis discriminatórias, visto a importância dos judeus na Reconquista dos séculos XI a XIII. O papel dos judeus tanto no financiamento e na administração dos novos territórios, quanto no povoamento das cidades abandonadas pelos muçulmanos, reveste-se de uma importância rara. Os reis castelhanos Fernando III e Afonso $\mathrm{X}$ e os aragoneses Jaime I e Pedro III (ou segundo na Catalunha) dependem dos judeus para executar os seus projetos de guerra. Por isso, as pressões de segmentos da sociedade e da Igreja se fazem inicialmente limitadas e contidas pelos interesses da Coroa e de segmentos da nobreza. Ainda assim, reis como Jaime I de Aragão devem permitir situações, conforme o debate teológico de Barcelona $(1263)^{6}$, para reduzir a pressão dos monges mendicantes. Em Castela, Fernando III e Afonso X conseguem autorização papal para não colocar em prática normas do IV concílio de Latrão (1215), entre as quais a insígnia infamante (rodela amarela). Diz Suarez Fernandez:

Cuando el IV Concilio de Letrán (1215) estabeleció en uno de sus cánones la segregación definitiva de los judios que serian obligados a portar un signo (la rodela amarilla) en su ropa exterior para advertir a los cristianos del peligro de su contagio, los monarcas Fernando III de Castilla y Jaime I de Aragón se dirigieron al papa Inocencio III señalando la inoportunidad de aplicar tales disposiciones en sus reinos donde los judios, desde tiempo antiguo, disfrutaban de un status jurídico diferente y valioso (1992: 20).

Esta concessão foi outorgada em caráter temporário por Honório III, sucessor de Inocêncio III, numa espécie de moratória, sem suspender a força e o vigor da Constitutio pro iudaeis (1199) de Inocêncio e tampouco dos cânones conciliares. 
Cabe enfatizar que prevalecem linhas mestras que são tendências que se mantêm desde as leis baixo-imperiais e dos primeiros concílios ecumênicos. Os judeus não podem ter poder e superioridade evidente diante dos súditos e fiéis cristãos, não podem fazer proselitismo com cristãos ou pagãos, sejam estes livres ou escravos, não podem transitar pelo "espaço cristão" de maneira aleatória, devendo ser controlados e demarcados no tempo e no espaço, devem ser protegidos pelas autoridades cristãs dentro do espírito da lex e da teologia agostiniana, mas de maneira que não burle o primeiro item, acima citado. Analisaremos a partir daqui estas vertentes em alguns casos perceptíveis tanto na lei romana quanto nas codificações germânicas, enfatizando as leis e cânones visigodos, visto serem a base das leis medievais castelhanas e ibéricas em geral. $\mathrm{E}$ junto com isso, mostraremos sua continuidade nas Partidas de Afonso. Assim, perceberemos elementos de longa duração e, em contraponto, demarcaremos as novas tendências que não têm origem direta no Baixo Império e nem na Patrística, mas que são frutos das novas conjunturas sociais, políticas e econômicas.

\section{Os judeus na legislação medieval castelhana: De los Judios}

Ao debruçarmo-nos sobre a Sétima Partida, percebemos que no título XXIV, a temática é focada na presença judaica no Reino de Castela. Algumas problemáticas gerais perpassam o texto jurídico: a) a necessidade dos judeus na administração e nas finanças do reino não é declarada, mas está nas entrelinhas do texto, pois o monarca os protege mesmo que de maneira ambígua, já que o texto legal os define como deicidas e suspeitos de malignidade; b) a separação de judeus e cristãos se sobressai em quase todos os artigos; c) há tensões sociais e religiosas no seio da população e, portanto, há que defender os judeus de violência e conversões forçadas; d) há novas percepções sociais e teológicas sobre os judeus, que são preconceituosas e começam a aparecer no texto jurídico. 
Delimitemos agora nosso objeto de pesquisa em alguns tópicos e tratemos de desenvolvê-lo por problemáticas específicas. Optamos pelas seguintes temáticas: a) a separação social e religiosa entre judeus e cristãos, b) o status jurídico diferenciado, incluindo os direitos e privilégios judaicos, c) os preconceitos e mitos anti-judaicos.

\section{A) Separação entre judeus e cristãos}

Em toda a Cristandade, a preocupação com o contágio judaico perpassa a legislação e aparece em gestos, pregações e escritos. Um dos precursores desta concepção de separação vem do Oriente (séc. IV d.C.), e é talvez o exemplo mais radical: João Crisóstomo, em Antioquia, que proferiu uma vasta série de sermões antijudaicos, agudamente agressivos e articulados sob uma retórica impiedosa que compara os judeus ao demônio (FLANNERY, 1968: 66; PARKES, 1974: 164; v. também SILVA, 2007). É evidente o receio do contato e o desejo de isolar o rebanho da influência judaica. Isso se repete em Agostinho, Jerônimo e Gregório Magno (FELDMAN, 2004) e também em Isidoro de Sevilha (FELDMAN, 2005).

A lei baixo imperial é minuciosa em definir limites aos judeus. As leis relativas aos judeus no Codex Theodosianus e posteriormente no de Justiniano legalizam o cerco pretendido pela Igreja, aliada do poder temporal. Os judeus não podem se relacionar com os cristãos em muitos níveis. A separação dos judeus e das mulheres não judias, forçando a endogamia e impedindo os casamentos mistos e a possível conversão de mulheres não judias ao Judaísmo, foi decretada por Constâncio, filho de Constantino, em lei de 13 de agosto de 339 (MOMMSEN; MEYER (CT), 1954: XVI, 8, 6). A exclusão e a endogamia é forçada pelo Estado no intuito de impedir a conversão de esposas e concubinas.

A separação parte do receio do clero de que a contaminação judaica se espalhe. Esta é talvez uma das preocupações iniciais da Igreja na Península Ibérica e que pode ser perceptível já no Concílio de Elvira ocorrido na primeira 
década do séc. IV e um pouco antes da aproximação da Igreja e do Estado romano sob a custódia de Constantino, o grande. Em Elvira há cânones que enfatizam a preocupação da Igreja pela influência dos judeus sobre os cristãos: proíbem o casamento dos que comungam por Jesus com gente de outra fé, seja com judeus, seja com hereges (cânone 16); ameaçam com excomunhão de até cinco anos, aos fiéis casados que cometam adultério com mulheres judias ou pagãs (cânone 78); instituem a proibição de que os judeus abençoassem os campos e as arvores de camponeses ou senhores de terra cristãos (cânone 49). O cânone mais notável é aquele que delimita os contatos sociais entre os seguidores da Igreja e os praticantes da Lei Antiga: é o quinquagésimo, que define a proibição de refeições entre judeus e clérigos ou simples fiéis cristãos (ASSIS, 1988: 40-41; MARCUS, 1938: 101-102).

Em concílios da Igreja na Gália e na Itália, nos séculos que seguem Elvira (séc. IV a VI), percebem-se tais posturas de tentar isolar, de forma semelhante a atitude de João Crisóstomo que citamos anteriormente no nosso texto. Uma das posturas mais facilmente perceptíveis foi a de separar e distinguir com clareza o Sábado do Dia do Senhor (Domingo) e a Páscoa cristã do Pessach ou Páscoa judaica (MARCUS, 1938: 103-106). Há uma clara percepção de que evitar o convívio e o contágio entre a religião mãe e a religião filha era fundamental para a definição da maneira cristã de ser. Separar para manter a identidade definida e a herança da Revelação e da Eleição exclusivamente no campo da Igreja. Ao debruçarmo-nos sobre as Sete Partidas, percebemos que há algumas leis que refletem a proposta de separação. Explicitaremos a legislação que a define em subtópicos.

\section{A 1) Sociabilidade e relações cotidianas}

A oitava lei determina que "[...] defendemos que ningunt cristiano nin cristiana non convide á ningunt judio nin judia, nin reciba otrosi dellos para comer nin beber en uno [...]" (ALFONSO X, 1807: Part. VII,Tit. XXIV, Ley VIII, p. 673). 
Isto não é uma novidade, mas uma permanência do cânone cinquenta de Elvira. A novidade provém do fato que, em Elvira, apenas se salienta que o fiel ou clérigo que opte por fazer refeições com judeus fica excluído da comunhão (ASSIS, 1988: 40; MARCUS, 1938: 101-102). Na oitava lei se frisa na sequência duas novidades: não beber do vinho dos judeus mesmo se não estiver em sua companhia. Isto se junta com a sequência da mesma lei que frisa que um cristão não deve ingerir remédio manipulado por médico judeu, salvo se receitado pelo mesmo, mas manipulado e revisado por um médico cristão. $O$ texto diz assim: "[...] nin beban del vino que es fecho por mano dellos. [...] que ningun cristiano non reciba melecinamiento nin purga que sea fecha por manos de judios [...]" (ALFONSO X, 1807: Part. VII,Tit. XXIV, Ley VIII, p. 673).

Aqui está implícita uma contradição e uma novidade. O monarca Afonso X, o Sábio, confiava o erário real a financistas e cobradores de impostos judeus assim como seu pai o rei Fernando o fizera e assim como o fariam a maioria dos reis castelhanos e o que é mais importante: os monarcas eram tratados por médicos judeus. A lei não vale na corte que usufrui da medicina judaica. A novidade é a suspeita de que os judeus envenenam os cristãos e que não se deve fazer uso de alimentos que eles tenham tocado e nem de médicos judeus. Esta legislação traz influência visível dos mitos criados e desenvolvidos na região transpirenaica nos séculos anteriores ao XIII. Voltaremos a analisar este mito na sequência.

Uma outra advertência incomum determina que judeus e cristãos não devam banhar-se juntos, o que pode talvez trazer uma referência a atração de que os rituais judaicos exerciam sobre os cristãos. Mesmo considerando que na Hispânia medieval os muçulmanos introduziram os costumes dos banhos e reciclaram à sua maneira os costumes da aristocracia romana, vale lembrar que os judeus tinham por hábito, o banho ritual denominado mikve. Este era realizado antes das festas, do casamento e, no caso feminino, após o final da menstruação. $O$ banho ritual servia também como ato secundário para o rito da conversão, além é óbvio da circuncisão masculina. Nota-se aqui 
o receio de proximidade e também da conversão. O texto é conciso: "Et aun mandamos que ningunt judio sea osado de bañarse em baño en uno con los cristianos". (ALFONSO X, 1807: Part. VII,Tit. XXIV, Ley VIII, p. 673)

\section{A 2) Utilização de trabalho/ relações de poder entre judeus e cristãos}

Remontam ao Codex Theodosianus as proibições que tratam de evitar que ocorram relações de superioridade através das quais judeus possam influenciar cristãos, sejam tanto escravos quanto assalariados serviçais de qualquer tipo. Não era permitido que um judeu tivesse um cargo que lhe propiciasse uma posição hierárquica superior a um cristão, tal como liderança militar ou função pública administrativa. Os judeus foram ejetados do serviço militar e da administração pública, salvo das cúrias municipais romanas, que geravam mais dissabores e prejuízos econômicos do que poder (MOMMSEN; MEYER (CT), 1954: XVI, 8, 16). Este conceito perpassa as legislações bárbaras, tal como o Breviário de Alarico (506) e prossegue nas Partidas. Se um judeu tivesse poder sobre algum cristão poderia influenciar o fiel a se converter ao Judaísmo.

As Partidas permitem que cristãos livres trabalhem em espaços abertos para judeus, seja no campo e seja na parte externa de seus lares, mas nunca no interior de suas casas. Poderiam servir de guias e supomos que também como seguranças em trajetos que a lei define "[...] cuando hubiesen de ir por algún lugar dudoso" (ALFONSO X, 1807: Part. VII,Tit. XXIV, Ley VIII, p. 673).

A postura é mais radical quando se aborda a questão da posse e conversão de escravos por judeus. Na legislação romana há claras proibições e fica bem definida a motivação de evitar o proselitismo judaico com seus escravos. Em lei de 339, Constâncio determina que se os judeus adquirissem escravos que não fossem da mesma etnia, estes seriam confiscados pelo governo (MOMMSEN; MEYER (CT), 1954: XVI, 9, 2). Há uma 
clara intenção de impedir conversões, visto permitir aos judeus ter escravos judeus e não emancipar os escravos pagãos ou cristãos, apenas alterando a posse dos mesmos e repassando-os ao Estado. Os bárbaros mantiveram esta postura. Entre as leis incorporadas ao Breviário de Alarico, ainda sob o período ariano, há algumas relativas a escravos e ao proselitismo que nos interessam. Uma delas determina que o judeu que convertesse um não-judeu (entenda-se: circuncidasse), livre ou escravo, seria punido com a morte e o confisco de seus bens (FELDMAN, 2002: p. 151). Imediatamente após o III Concílio de Toledo (589), quando os visigodos se tornaram católicos, ocorre um alteração notável.

O rei Recaredo decretou que os judeus não poderiam obter e tampouco manter escravos cristãos, não importando como fosse a aquisição: por compra, por doação ou presente. Os escravos assim adquiridos seriam libertados, mas nenhuma punição foi fixada para o senhor judeu. Após a conversão forçada dos judeus por Sisebuto, instaura-se um período que não levaremos em conta por ser pouco definido. Quem são os judeus: seriam os neófitos cristãos oriundos das conversões forçadas ou seriam judeus que retornaram sob reis mais tolerantes? O tema da posse de escravos pelos possíveis judeus, de Sisebuto até a invasão árabe já analisamos em outro artigo. (FELDMAN, 2002)

O controle e as proibições acentuam-se no transcorrer do século VIII, impedindo a posse de escravos aos judeus. Essa postura reaparece no Fuero Juzgo, que é uma legislação que tem por base a Lex Visigothorum de Recesvinto (654) e emendada por outros monarcas até 711. No Fuero Juzgo, décimo segundo livro, há leis relativas aos judeus que reciclam leis de Recesvinto e Ervígio. Numa delas, há a explícita declaração de que um servo de um judeu que se converta ao Cristianismo deveria ser libertado. A lei pode não ter sido praticada em vista da falta de controle e capacidade dos monarcas de pô-la em prática, mas gera uma continuidade na essência da letra. Diz o texto:

E por ende establecemos que si algun siervo de judio, quier varón, quier muger, fuere sometido so su servidumbre, é quisiere venir a 
la ley de Cristo, non ge lo deviede la servidumbre, ni lo asconda de la fe nenguna cosa, ni lo contraste nenguno, niu lo asconda della nengun achaque, que en qual tiempo quierque s' aclamare, e connociere, e dixiere, e jurare ques cristiano, o que $s^{\prime}$ ha fecho cristiano, e descubriere la descreencia de sus sennores, e negare el su error, en aquella ora salga libre [...] (FUERO JUZGO, 1847: Livro XII, Tit. III, Ley 18, p. 199) (Grifo é nosso).

Nas Partidas, o problema volta à tona e sem dúvida nunca deixou de haver controles e restrições ditados pela Igreja e pelos reis. O medo de que judeus convertessem seus escravos cristãos é um fenômeno de média e longa duração. A conversão pode libertar o escravo em função da lei do ano sabático, na qual os judeus escravizados seriam alforriados após seis anos, readquirindo sua liberdade, e que consta da Lei mosaica (Deuteronômio, cap.15, vers. 12-15).

Afonso determina com clareza a preocupação que os judeus não possuam e nem comprem escravos cristãos: "Comprar ni tener no deben los judíos por sus siervos hombre ni mujer que fuesen cristianos" (ALFONSO X, 1807: Part. VII,Tit. XXIV, Ley X, p. 674). Se o judeu tiver adquirido ou possuir um escravo cristão deve libertá-lo sem ser ressarcido pelos seus gastos, mesmo se não tivesse sido informado que o escravo era cristão. No caso de estar informado, persistir na compra e usufruir do escravo para seu serviço, seria condenado à morte. "Mas si supiese el judío que lo era cuando lo compró y se sirviese después de él como de siervo, debe el judío morir por ello" (ALFONSO X, 1807: Part. VII,Tit. XXIV, Ley X, p. 674). Esta medida poderia dar vazão a acusações sem fundamento e até permitir a um escravo pagão, mouro ou judeu obter sua alforria, alegando ser cristão ou simplesmente se convertendo. Este tipo de lei gera um deslocamento dos judeus da posse e usufruto de terras, visto que a agricultura intensiva só poderia ser praticada com o suporte de escravos ou colonos ou servos, de acordo com o momento e com as condições locais.

O judeu podia ter escravos mouros ou pagãos, mas não poderia convertê-los. Esta posição é também originária da lex 
baixo-imperial. A sua manutenção atesta o cerco contínuo da Igreja e do poder temporal, seja qual for em impedir o proselitismo judaico. O teor da décima lei da vigésima quarta partida é claro: está proibida a conversão de escravos mouros ou pagãos ao Judaísmo e os senhores que o fizessem perderiam a posse dos mesmos (ALFONSO X, 1807: Part. VII,Tit. XXIV, Ley X, p. 674). A essência da lei é de longa duração: judeus não podem ter influência sobre todo e qualquer escravo ou servo a fim de impedir que o convertam. Desde o Baixo Império se legisla tentando evitar a posse de escravos cristãos por senhores judeus no intuito de impedir sua eventual conversão.

A lei de Afonso X, nesse caso, assemelha-se à legislação visigótica vigente sob Recaredo e depois por outros reis visigodos, a qual vedava a aquisição e posse de escravos cristãos pelos judeus, previa que no caso de conversão do escravo ao Cristianismo, os judeus perderiam a posse e o controle destes escravos. Este conceito nunca foi revogado por nenhum rei visigodo. Só foi atenuado somente e salvo se o senhor judeu se convertesse ao Cristianismo, podendo então manter seus escravos, sendo pagãos, judeus ou mesmo cristãos (FELDMAN, 2002).

Nas Partidas, a lei agrega a opção de um escravo muçulmano que pertencesse a um senhor judeu obter a alforria se e caso se convertesse ao Cristianismo. O texto enfatiza: " $Y$ si por ventura algunos moros que fuesen cautivos de judíos se tornasen cristianos, deben ser luego libres por ello" (ALFONSO X, 1807: Part. VII,Tit. XXIV, Ley X, p. 674). Restava aos judeus terem escravos pagãos e mouros desde que estes não optassem por se tornar cristãos, ou ter escravos judeus. Não se permitiam e nem se admitiam relações de poder dos judeus "infames" em relação a fiéis cristãos.

\section{A 3) Conversão de cristãos ao Judaísmo}

Se a conversão de escravos era controlada e proibida, a de cristãos em geral era sumariamente definida como passível de pena de morte. A sétima lei entre as relativas aos judeus é 
sucinta e direta. Todo e qualquer cristão que se convertesse ao Judaísmo sofreria a pena de morte, pois estava atuando como se fosse um herege: "Tan malandante siendo algún cristiano que se tornase judío, mandamos que lo maten por ello, bien así como si se tornase hereje" (ALFONSO X, 1807: Part. VII,Tit. XXIV, Ley VII, p. 673). Percebe-se aqui uma continuidade mesclada com uma nova tendência. A posição da Igreja em relação aos albigenses, a instauração da Inquisição no Languedoc (sul da França), na primeira metade do século XIII, faz da heresia uma questão de lesa majestade. O herege e o judeu começam a ser vistos como o resultado de um mesmo conflito entre a Igreja e a malignidade. Não resta dúvida que o cerco aos hereges e à contaminação judaica, que já era intenso, agudiza-se ainda mais.

\section{A 4) Conversão de judeus ao Cristianismo}

A conversão dos judeus ao Cristianismo é mais que um desejo, pois se apresenta quase como uma pré-condição para a segunda Encarnação de Cristo, na concepção teológica de muitos dos Padres da Igreja e teólogos medievais. Portanto, deve ser estimulada e os conversos protegidos. Na lei baixoimperial romana havia severas advertências aos judeus que atacassem ou tentassem apedrejar os seus ex-irmãos que se tornassem neófitos cristãos.

Protegê-los de todas as formas e impedir que parentes e antigos irmãos o ferissem ou lhe privassem de bens, heranças familiares e outras benesses.

Há uma tentativa jurídica de impedir a discriminação dos neófitos pelos cristãos, que se revelará ineficiente no contexto pós 1391, quando as conversões forçadas criarão uma enorme quantidade de "cristãos novos", valendo frisar que se trata um termo anacrônico neste contexto. O texto é direto e se tornará letra morta na realidade dos séculos XV e seguintes:

Otrosí mandamos que después que algunos judíos se tornasen cristianos, que todos los de nuestro señorío los honren, y ninguno sea osado de retraer a ellos ni a su linaje de como fueron judíos en 
EXCLUSÃO E MARGINALIDADE NO REINO DE CASTELA:...

manera de denuesto (ALFONSO X, 1807: Part. VII,Tit. XXIV, Ley VI, p. 672-673).

A ironia histórica é que quem irá discriminar mais e fustigar os convertidos após 1391 serão certos setores sociais cristãos "velhos" que não aceitarão a inclusão social e religiosa dos neófitos por temerem que sua inserção social gerasse perda de status e direitos aos já estabelecidos, tal como a teoria de Norbert Elias sobre os estabelecidos e os outsiders (ELIAS; SCOTSON, 2000). Deve-se ressaltar que há fatores irracionais que são de longa duração: o batismo gera purificação ao fiel, mas não retira a mácula judaica na consciência popular e nos enraizados mitos da malignidade judaica.

A lei das Partidas que legisla sobre a proibição da conversão forçada dos judeus segue os critérios do Papa Gregório Magno e de Agostinho. Não se devem forçar as conversões de judeus.

Fuerza ni apremio no deben hacer en ningún modo a ningún judío por que se torne cristiano, mas con buenos ejemplos y con los dichos de las Santas Escrituras y con halagos los deben los cristianos convertir a la fe de Jesucristo, pues nuestro señor no quiere ni ama servicio que le sea hecho por apremio (ALFONSO X, 1807: Part. VII,Tit. XXIV, Ley VI, p. 672).

Eis aqui mais uma lei que ficou na teoria e não foi obedecida em 1391. A onda de conversões forçadas e o terror social que se criou nos reinos ibéricos foi uma afronta e um descaso em relação à concepção de que as conversões se tratavam de um assunto de crença e só podiam ser feitas através do convencimento, da pregação e de maneira pacífica e terna.

\section{A 5) Relações sexuais entre cristãos e judeus}

O olhar tradicional vigente na legislação baixo-imperial romana era impedir que o proselitismo judaico se propagasse através da conversão de esposas e concubinas ao Judaísmo e a 
circuncisão de filhos destas uniões, aumentando a presença e a importância judaica na sociedade. Na lei castelhana este tipo de relacionamento é ampliado. A lei nove denomina como ousadia e atrevimento a atitude dos judeus que coabitam (yacen=deitamse) com cristãs, sem diferenciá-las: trata igualmente da mulher casada, viúva virgem ou até uma rameira. Em todos os casos, seria algo semelhante a uma relação adulterina. Decreta que os judeus que o fizerem serão mortos, comparando tal transgressão como o adultério entre cristãos, que faz merecer a punição capital. Isto porque a mulheres cristãs são "espiritualmente esposas de Jesucristo por la razón de la fe del bautismo que recibieron en nombre de él" (ALFONSO X, 1807: Part. VII,Tit. XXIV, Ley IX, p. 674). Não qualificando tipos de mulheres e apenas remetendo a lei similar que consta da legislação sobre os mouros, onde se definem as diversas penas a que eram submetidas as mulheres que coabitavam com muçulmanos, acabaram-se generalizando os diversos casos em uma pena apenas. Judeus que tivessem relações carnais indistintamente com mulheres virgens, casadas, viúvas e até mesmo "mujer baldonada que se dé a todos" seria punido com a pena de morte, por se tratar sempre de adultério. Isso quando analisa a pena dos homens infiéis que transgridem o limite e interagem com mulheres cristãs.

Já as mulheres cristãs que coabitem com judeus ou mouros são punidas de acordo a sua condição conjugal. As virgens perderiam metade de seus bens ao copularem com mouro ou judeu, à primeira vez, mas, se persistissem no erro, perderiam o restante de seus bem e seriam mortas. Se fosse uma viúva a situação seria igual. A mulher casada seria entregue ao esposo que poderia perdoá-la ou sentenciá-la a morte, de acordo a sua vontade. A prostituta seria açoitada, pela primeira vez, junto com seu parceiro infiel, à segunda, seriam ambos justiçados.

O mouro que coabitasse com cristã virgem, casada ou viúva seria apedrejado. Só no caso de mulher pública seria açoitado na primeira e só seria morto na segunda vez (ALFONSO X, 1807: Part. VII,Tit. XXV, Ley X, p. 681). Em relação aos judeus, observa-se uma diferente postura no caso das rameiras, visto 
não haver uma primeira oportunidade. Portanto, na essência, a contaminação judaica ou muçulmana é controlada até em relação às prostitutas. As relações carnais entre cristãos e infiéis são vedadas e punidas com severas penas, independente da condição social e conjugal, como um pecado capital. Nada encontramos que fale sobre as relações entre homens cristãos e mulheres judias. Podem-se ter duas deduções que não se anulam: não havia contatos entre mulheres judias e cristãos; mas se houvessem, não eram proibidos por lei. Em ambas as hipóteses há certa dose de misoginia e de descaso com a pretensa honra e dignidade das mulheres e das famílias dos infiéis.

\section{B) Proteção aos judeus: direitos e privilégios judaicos}

Há uma reminiscência jurídica do status de "religio licita" que aparece nas Partidas e que pode ter sido importado do Direito Romano que renascia no século XIII ou ser uma versão das posições de Gregório Magno e Agostinho. Possivelmente, ambos os fatos, na nossa compreensão, visto não serem antagônicos. A proteção das sinagogas preexistentes é uma legislação que remonta aos conflitos entre Teodósio, o Grande, e o Bispo Ambrósio de Milão, na questão da destruição da sinagoga de Callinicum no final do quarto século (FELDMAN, 2001). No Codex Theodosianus, determina-se que as sinagogas que existissem não poderiam ser destruídas, mas tampouco ampliadas ou aumentadas. Deveriam permanecer como estavam. Uma espécie de status quo. Gregório Magno reforça e mantém esta postura que servirá para que monarcas de postura moderada e tolerante propiciem aos judeus que vivam sua vida comunitária de maneira plena e autônoma, ainda que em isolamento e exclusão social em relação à sociedade cristã (FELDMAN, 2004).

Nas Partidas temos duas leis amplamente explicitadas que abordam o direito à vida comunitária e religiosa dos judeus. Repete e mantém a antiga postura de continuidade das sinagogas pré-existentes: "Pero las que había antiguamente, si 
acaeciese que se derribasen, puédenlas reparar o hacer en aquel mismo suelo así como antes estaban, no alargándolas más ni alzándolas ni haciéndolas pintar" (ALFONSO X, 1807: Part. VII,Tit. XXIV, Ley IV, p. 671). Insiste na posição de que não se construam novas sinagogas, nem se aumentem as existentes. Toda e qualquer nova sinagoga seria confiscada e entregue à Igreja, mas deixa uma sugestiva ressalva: "[...] a menos de nuestro mandato". Ou seja, o rei pode autorizar a construção de novas sinagogas e ampliação das já existentes.

O recinto da sinagoga é protegido. Cristãos não podem lá entrar durante as orações, mesmo se tiverem uma queixa judicial. Estão proibidos de pernoitar no seu recinto e penetrar no mesmo com bestas (cavalos ou outros). O tempo sagrado do Shabat (da sexta ao anoitecer ao entardecer do sábado), o dia do descanso e da oração intensa deve ser preservado. O Sábado judaico recebe uma aura de imunidade, pois um cristão não pode demandar ou pleitear queixas ou intimar judicialmente um judeu no Shabat. Esta postura se coaduna com o amplo conhecimento que o rei Afonso tinha dos judeus que circulavam em sua corte e lhe prestavam serviços financeiros, administrativos, médicos e de tradução de textos do grego e do árabe principalmente.

Afonso tem um apreço disfarçado pelos judeus que contrasta com as posturas de sua época. Tudo aparenta ser contraditório, mas tem fundamento na realidade cotidiana e na interação de alguns reis com os judeus que pertenciam a sua corte e lhes prestavam serviços. Não deixa de frisar sua culpa, sua cegueira e seu erro ao não aceitar a Cristo. Não deixa de inserir mitos e concepções preconceituosas em voga no Medievo. Mas tem noção do papel judaico na vinda de Cristo e na sua venerável condição de povo tradicional. Nas palavras de CARPENTER: "[...] Alfonso briefly notes the Jews adherence to a venerable legal tradition and praises them for certain ethical and political qualities" (1986: 59).

Há uma clara intenção de respeito ao espaço de louvor de Deus: "Y porque la sinagoga es casa en donde se loa el nombre de Dios, prohibimos que ningún cristiano no sea osado de quebrantarla ni de sacar de allí, ni de tomar ninguna cosa por 
EXCLUSÃO E MARGINALIDADE NO REINO DE CASTELA:...

fuerza [...]" (ALFONSO X, 1807: Part. VII,Tit. XXIV, Ley IV, p. 671).

No que tange a vida comunitária judaica, temos evidências de que Afonso deu plenos poderes aos judeus para gerir seus bairros e instituições religiosas, educacionais e sociais. A autonomia jurídica interna já existente foi mantida e até ampliada. Baer afirma que "Alfonso apoyó de manera ostensible el aumento de autonomía en la organización de las comunidades judias. [...] Los judíos gozaban de amplísimos derechos en cuanto la jurísdición penal [...]" (II, 1981: 94).

\section{C) Novas tendências: os preconceitos e mitos anti-judaicos}

A onda de preconceito estava em plena penetração na Península Ibérica, já tendo atravessado os Pirineus e trafegando em meio às crenças e ao imaginário social. Um dos mitos que percebemos em evidência é a acusação de crime ritual. Originário da Inglaterra, onde o caso de Guilherme de Norwich (1144) foi o estopim de uma acusação fictícia e de um estereótipo que teve longa duração e chegou ao limiar do século XX com o caso Beilis na Rússia Czarista. O eixo deste mito seria a execução através do martírio, geralmente crucifixão de um cristão. A maioria das vezes eram crianças inocentes ou jovens de quem o sangue era retirado e usado para a confecção do pão ázimo (matzá) utilizado na Páscoa judaica (Pessach). A proximidade com a Páscoa cristã e a lembrança do martírio e da morte carnal do Cristo, acirrava os ânimos e aguçava as emoções.

Aqui Afonso X se posiciona como um homem de seu tempo. Não se coloca como acusador, mas tampouco se exime de deixar a dúvida e a possibilidade de que a acusação venha a ter fundamento. A inserção da acusação ritual como uma possibilidade jurídica é o reconhecimento de sua possível veracidade. Alimenta o preconceito e dá-lhe uma aura de possível fato ao alocá-lo nas entrelinhas da lei: 
Y porque oímos decir que en algunos lugares los judíos hicieron y hacen el día del Viernes santo memoria de la pasión de nuestro señor Jesucristo en manera de escarnio, hurtando los niños y poniéndolos en cruz o haciendo imágenes de cera y crucificándolas cuando los niños no pueden tener, mandamos, que si fama fuere de aquí en adelante que en algún lugar de nuestro señorío tal cosa sea hecha, si se pudiere averiguar, que todos aquellos que se acertaren en aquel hecho que sean presos y recaudados y conducidos hasta el rey, y después que él supiere la verdad, débelos mandar matar vilmente a cuantos quiera que sean (ALFONSO X, 1807: Part. VII,Tit. XXIV, Ley II, p. 670).

O destaque que a lei adquire, ao ser alocada como segunda lei do vigésimo quarto título e a maneira pela qual Afonso postula certo grau de veracidade ao afirmar que "ouvimos dizer que em alguns lugares os judeus fizeram e fazem", evidencia que se trata de um rumor bastante passível de verossimilhança e portanto já legisla a pena para o caso deste ocorrer em seus domínios. Afonso $\mathrm{X}$ descreve também um caso de crime ritual na Cantiga 12 de suas cantigas de Santa Maria (CARPENTER, 1986: 65 e nota 13). Há, portanto a aceitação parcial de não ser um rumor ou calúnia.

Aqui se percebe a postura ambígua do soberano que protegeu os judeus durante seu reinado e não arrefeceu em colocá-los em cargos de confiança na administração e dotá-los de terras, direitos e honras. Na sua insinuação sobre os riscos de envenenamento quando se fizesse uso de médicos judeus (V. acima) ele também incide numa contradição visto o uso de médicos judeus na corte real. A maioria absoluta dos médicos dele e de seu pai Fernando III eram judeus (BAER, 1981: 97). Muitos médicos judeus cuidavam de reis e de elementos da alta nobreza na Península Ibérica antes e depois desta lei.

A resistência ao uso dos sinais distintivos nos reinos ibéricos é notável. Imediatamente após o IV Concílio de Latrão (1215), que decretou o uso de roupas e sinais distintivos aos infiéis, os judeus, em 1219, advertiram ao rei Fernando III que iriam deixar seu reino e migrar para os reinos mouros se este colocasse em uso a utilização de roupas e sinais diferenciadores. 
EXCLUSÃO E MARGINALIDADE NO REINO DE CASTELA:...

Fernando obteve do papa Honório, isenções temporárias (CARPENTER, 1986: 100).

Concessões foram feitas de maneira menos absoluta em Aragão ao rei e a alguns bispos. A inserção da décima primeira lei no conjunto do título vigésimo quarto demonstra que mudanças ocorreram. $O$ sinal diferenciador estava sendo instituído e legalizado, devagar e de maneira parcial. A lei traz alguns aspectos bem definidos: a punição por dez maravedis ou dez chibatadas aos judeus contraventores, a necessidade de separar os judeus e evitar a intimidade social, talvez até carnal, entre eles e os cristãos. Fica bastante tímida ao definir o sinal que os distinguiria: não fala do sinal infamante ou da rodela amarela. Ordena de forma tímida e imprecisamente que "traigan alguna señal cierta sobre sus cabezas, y que sea tal por la que conozcan las gentes manifiestamente cuál es judío o judía" (O grifo é nosso) (ALFONSO X, 1807: Part. VII,Tit. XXIV, Ley XI, p. 675).

Esta é mais uma mudança que ainda se prenuncia contida, mas que tende a aguçar-se no século quatorze com a pressão das ordens mendicantes, das Cortes e de elementos da nobreza que percebem o interesse dos reis nos judeus e como estes servem para fortalecer sua tentativa de centralização e uniformização do reino.

\section{Conclusões Parciais}

A nossa proposta foi demonstrar as permanências e continuidades da legislação relativa aos judeus na Península Ibérica medieval. Fizemos comparações entre aspectos da legislação romana e visigótica com as Siete Partidas, tentando demonstrar tais conexões de média e longa duração. Do mesmo modo tentamos demonstrar as novas tendências e olhares sociais relativos aos judeus: os mitos medievais, a crescente satanização da minoria judaica e a tendência à exclusão dos judeus do seio da maior parte da Cristandade Ocidental. A monarquia inglesa expulsa-os no final do século XIII, na 
sequência, a coroa francesa executa três expulsões em cerca de um século. No Império e na Itália, a pulverização política em muitos principados impede uma expulsão geral dos judeus.

Os reinos ibéricos não ficam impermeáveis a essa tendência: as pressões do clero, e em particular das ordens mendicantes se fazem sentir durante os séculos XIII e XIV. Alguns setores sociais se indispõem com a presença judaica e sua importância na corte dos reis, principalmente a baixa nobreza e os escassos burgueses nas cidades, além do clero é óbvia. Os indícios estão nos pedidos das Cortes e na própria legislação afonsina como os exemplos citados. A explosão culmina em 1391 com uma onda de ataques às aljamas e juderias e com a conversão forçada de milhares de judeus, colocados entre a espada e a cruz. O século XV será o palco de confronto entre a Igreja e os remanescentes judeus que deverão optar entre a conversão ou a expulsão, mais cedo ou mais tarde. Logo após a união das coroas de Castela e Aragão, ocorre o final da Reconquista em solo ibérico com a tomada de Granada e a expulsão dos judeus dos reinos unificados, ambos os fatos ocorrendo, não por acaso, no mesmo ano: 1492. Está encerrado o processo. Os indícios da mudança estão nas entrelinhas do texto das Siete Partidas.

A posição dos judeus no processo da Reconquista (séc. XII e XIII) em Aragão e Castela é de suma importância. A logística militar tem por base e apoio a forte presença de financistas e administradores judeus, tanto para ajudar a conquistar, quanto para ocupar e colonizar. Os judeus são peças chave do avanço cristão. Agregando-se seu saber do árabe e seu conhecimento da Andaluzia, podemos compreender o porquê da proteção que os reis lhes concediam.

Afonso X, especificamente, era um rei culto e cercou-se de sábios: astrônomos, tradutores, filósofos, poetas, médicos e outros. Muitos desses eram infiéis: ora judeus, ora muçulmanos. O legado cultural destes infiéis é notável, mas gerou rancores e ressentimentos. Esta forte presença de não cristãos na corte criou um clima que ora favorecia aos infiéis, ora gerava ondas de protestos entre a nobreza e, especialmente, no seio do clero. As 
ordens mendicantes almejavam resolver a problemática judaica e não é surpreendente que, paralelamente ao debate cristãojudaico de Paris (1240), tenha ocorrido outro em Barcelona (1263). O movimento de difusão do preconceito antijudaico vem do noroeste e vai adentrando a Península Ibérica: primeiro Aragão e Navarra, depois Castela e finalmente Portugal. O avanço é inexorável e a pressão é pela conversão ou expulsão dos judeus alienígenas.

$\mathrm{Na}$ legislação podemos perceber a presença de valores e concepções que poderíamos considerar como tolerantes, admitida a realidade e o contexto medievais. Os judeus podem viver sob o jugo da Cristandade, desde que numa condição de servidão: pertencem a um senhor cristão, geralmente o Imperador ou o rei. São elementos sociais de nível inferior, mesmo se forem de nível socioeconômico elevado. Espécie de párias, visto haver leis que impediam seu contato mais próximo com os cristãos. Não podiam conviver socialmente, nem fazer refeições ou provar alimentos que tenham sido tocados pelos judeus. A vida afetiva é absolutamente vedada, pois não podem sequer ter contatos sexuais com rameiras. Os judeus contaminam, seja com suas idéias e religiosidade distorcida, seja com sua malignidade, e agora com o veneno propriamente dito.

Um grupo marginalizado e discriminado só pode se manter se tiver uma função social e ou econômica. Desnecessários ou talvez apenas descartáveis? O final da Reconquista se mescla com a unificação parcial da Península Ibérica. $O$ ideal de unidade não possui base na diversidade lingüística, cultural e étnica das regiões que compõem o reino unido de Castela e Aragão. O regionalismo segue sendo evidente no século XXI e já o era no final do século XV. O cimento da unidade tende a ser o ideal cruzadista da Reconquista e a religiosidade comum a todos. Os judeus e seus descendentes são resquícios de uma era de diversidade e diálogo entre etnias ou religiões que a moderna "Espanha" quer esquecer e apagar de sua memória. 


\section{REFERÊNCIAS BIBLIOGRÁFICAS}

ALFONSO X. Las siete partidas del Rey Don Alfonso el Sábio. Madrid: Real Academia de Historia; Imprenta Real, 1807.

AGOSTINHO, A cidade de Deus. Lisboa: Fund. Calouste Gulbenkian, 1995.

AURELIUS AUGUSTINUS (AGOSTINHO). Enarratio, Psalmi. IN: Patrologia Latina, Paris: J. P. Migne, 1865. t. 36.

ASSIS, I.T. The Jews of Spain: from settlement to expulsion. Jerusalém: Hebrew Universitiy, 1988.

BAER, Yitzhak. Historia de los judíos en la España cristiana. Madrid: Altalena, 1982, $2 \mathrm{v}$.

BARON, S.W. História social y religiosa de pueblo judio. Buenos Aires: Paidós, 1968.

BEN SASSON, Haim Hillel (ed. e autor) Historia del pueblo judío 2: La Edad Media. Madrid: Alianza, 1988. Edição Hebraica (Tel Aviv: Dvir, 1969).

CARPENTER, Dwayne E. Alfonso $X$ and the Jews: an edition of and commentary on Siete Partidas 7.24 "De los judíos". Los Angeles, Berkeley: UCLA Press, 1986.

Catholic Encyclopedia On Line. IN: www.newadvent.org/cathen/

ELIAS, Norbert \& SCOTSON, John L. Os Estabelecidos e os Outsiders: Sociologia das Relações de Poder a partir de uma Pequena Comunidade.

Rio de Janeiro: Jorge Zahar, 2000.

FELDMAN, Sergio A. Agostinho de Hipona: a necessidade dos judeus na finalidade cristã da História. IN: SOUBBOTNIK, Olga Maria M. C. \& SOUBBOTNIK, Michael A. Enlaces: Psicanálise e Conexões. Vitória: G M Gráfica e Editora, 2008.

FELDMAN, S. A. De civis romanii a nefariam sectam: a posição jurídica da minoria judaica no Codex Theodosianus (séc. IV e V). IN: Revista da $S B P H$, Curitiba; SBPH, n. 21, 2001, p. 7-16.

FELDMAN, S A. A Igreja e a "questão judaica": de Eusébio de Cesaréia a Gregório Magno. Boletim do CPA. Campinas: Unicamp, v. 17, p. 131154, 2004.

FELDMAN, Sergio Alberto. Isidoro de Sevilha e a desmontagem do Judaísmo In: Relações de poder, educação e cultura na Antiguidade e Idade Média. Santana do Parnaíba: Solis, 2005 a, v.1, p. 341-352. 
FELDMAN, Sergio Alberto. Judeus, escravos e proselitismo na Espanha visigótica. IN: História: questões e debates. Curitiba: UFPR, ano 19, n.37, jul-dez 2002, p. 145-157.

FLANNERY, E.H. A angústia dos judeus: história do anti-semitismo. São Paulo: Ibrasa, 1968.

FONTETTE, F. História do anti-semitismo. Rio de Janeiro: Jorge Zahar, s.d..

FUERO JUZGO. IN: Códigos españoles:concordados y anotados. Madrid: Imprenta de la Publicidad, 1847. tomo I

KRIEGEL,Maurice. Judeus. IN: LE GOFF, Jacques \& SCHMITT, Jean Claude. Dicionário temático do ocidente medieval. Bauru: Edusc, 2006. t. II, p. 37-53.

MARCUS, Jacob R. The Jew in the medieval world: a source book (3151791). Cincinnati: UAHC, 1938.

MOMMSEN, T. \& MEYER, P. M. Codex Theodosianus. Berlim: [s.e.], 1954. (CT)

PARKES, J. The conflict of the Church and the Synagogue: a study in the origins of anti-Semitism. New York: Hermon, 1974.

SUÁREZ FERNANDEZ, Luis. La expulsion de los judios de España. Madrid: Mapfre, 1992.

SCHLESINGER, Hugo; PORTO, Humberto. Os papas e os judeus. Petrópolis: Vozes, 1973.

SILVA, Gilvan Ventura da. As relações de sociabilidade entre judeus e cristãos em Antioquia. In: Líber Intellectus, v. 2, p. 1-15, 2007.

FELDMAN, Sergio Alberto. Exclusion and criminality in the Kingdom of Castile: The Jew in the Siete Partidas (Seven-Part Code) of Alfonso X. História, v.28, n.1, p.589-620, 2009.

Abstract: The Jewish presence in the Medieval Iberian World was limited by the general normative rules that Western Christianity had defined for these followers of the Law of Moses, and was supplemented by the specific local legislation. The purpose of this study is to examine the Siete Partidas (Seven-Part Code) from the general Christian legislation and also from the scope of the medieval Hispanic world. This choice was formulated from the concept that in the core of this Code there is a confluence of theological-judicial concepts about the Jews, that had originated from the end of Antiquity, in the period of the 
Lower Empire and in the primordial times of the Middle Ages, hand in hand with the new concepts about Jews originating from the core of Western Christianity in the period of European expansion beginning from the year one thousand.

Keywords: Jews; Siete Partidas; Alfonso X; Castile; Exclusion.

\section{NOTAS}

${ }^{1}$ Fizemos a opção de colocar expressões em língua estrangeira em itálico. Isto vale para o Latim, para o Espanhol tradicional ou moderno, para o Inglês ou outra língua que não seja o Português. Nas citações, usaremos de aspas e se forem em língua estrangeira, agregaremos o itálico.

${ }^{2}$ Diz: "Ne occideris eos, ne quando obliviscantur legem tuam; disperge eos in virtute tua". Este trecho se baseia no Salmo 59, v.11 et seqs. (em algumas Bíblias, Salmo 58). Ao descrevermos os princípios norteadores da posição judaica, repetimos propositalmente o Salmo que é idêntico a esta citação.

${ }^{3} \mathrm{O}$ conceito de bibliotecário-escravo, de acordo a Flannery, op. cit., p. 69, existia na sociedade romana. Era um funcionário (escravo) instruído e que se sobrepunha aos outros escravos. Assemelha-se ao ponto de vista de Paulo sobre a Lei, como o "pedagogo em Cristo" (Gálatas c. 3, v. 24). Após a vinda do Cristo, a fé supera a Lei e iguala os fiéis, sendo estes os herdeiros de Abraão.

${ }^{4}$ Neste texto analisamos com mais ênfase a questão dos judeus na teologia e na filosofia da História agostiniana. Também percebemos a necessidade do judeu no confronto do Cristianismo com o maniqueísmo que negava o "Antigo Testamento" e desmontava o edifício cristão das Escrituras. Sem Antigo não há Novo; sem o Judaísmo anacrônico não se explica sua substituição pelo Cristianismo que trará a Redenção e a consecução da Finalidade da História.

${ }^{5}$ Este é o trecho do Salmo relativo à nota explicativa número 1. Tornase um dos pilares da concepção do judeu na sociedade cristã medieval. ${ }^{6}$ Debate entre um judeu convertido, denominado Pablo Christiani, assessorado pelos dominicanos com o sábio judeu Nachmânides. Versou sobre dogmas, a verdade cristã e o Talmud, entre outros temas.

Artigo recebido em 03/2009. Aprovado em 05/2009 